\title{
A quem pertence o termo "católicas"? Direito e mídia como arenas e estratégias do neoconservadorismo
}

\author{
To whom does the term "Catholic" belong? \\ Law and media as arenas and strategies of neoconservatism
}

\author{
Maria José Rosado Nunes ${ }^{\mathrm{a}} \odot$, Olívia Bandeirab ${ }^{\mathrm{O}}$, Gisele Cristina Pereira ${ }^{\mathrm{c}} \odot$
}

Resumo O artigo analisa formas de atuação do neoconservadorismo brasileiro por meio de estudo de caso: a ação judicial movida pela associação de leigos católicos Centro Dom Bosco de Fé e Cultura (CDB) contra Católicas pelo Direito de Decidir (CDD). O objeto da ação é a retirada do termo "católicas" da razão social da CDD com o argumento de que sua defesa dos direitos sexuais e reprodutivos estaria em desacordo com os fundamentos do catolicismo. Discute-se, a partir da ação, duas dimensões do neoconservadorismo: a juridificação reativa e sua disseminação pelas mídias e redes sociais (economia da performance). Os dados utilizados são documentos do processo judicial, iniciado em 2018, e a repercussão da sentença judicial que deu ganho de causa ao CDB publicada nas redes sociais das entidades e na mídia, entre outubro e novembro de 2020. O artigo conclui que a ação se insere num contexto mais amplo de ataques aos direitos humanos e à própria democracia e revela disputas no interior do catolicismo. Também conclui que, embora a atuação histórica do catolicismo tenha contribuído para a manutenção das estruturas conservadoras na sociedade brasileira, há elementos que diferenciam a atuação político-religiosa contemporânea no campo do catolicismo.

Palavras-chave Neoconservadorismo. Juridificação reativa. Performance midiática. Catolicismos. Direitos sexuais e reprodutivos.

Abstract The article analyzes how Brazilian neoconservatism works through a case study: the lawsuit brought by the Catholic lay association Centro Dom Bosco de Fé

a Doutora em Ciências Sociais pela Escola de Altos Estudos em Ciências Sociais (EHSS) de Paris, França, professora na PUC São Paulo, pesquisadora CNPQ e coordenadora do grupo de pesquisa Gênero, Religião e Política (GREPO), fundadora e integrante do Conselho Institucional de Católicas pelo Direito de Decidir/ Brasil. E-mail: mjrosado@uol.com.br

b Doutora em Antropologia Cultural (PPGSA-UFRJ), coordenadora de formação, pesquisa e articulação internacional do Intervozes - Coletivo Brasil de Comunicação Social, integrante do GREPO - Grupo de pesquisa em Gênero, Religião e Política (PUC-SP) e do LAR - Laboratório de Antropologia da Religião (Unicamp). E-mail: oliviabandeira@gmail.com

c Formada em História (UNESP), com especialização em Ciência da Religião (PUC-SP), mestranda em Ciência da Religião (PUC-SP), integrante do GREPO - Grupo de pesquisa em Gênero, Religião e Política (PUC-SP). Coordenadora de Católicas pelo Direito de Decidir/ Brasil. E-mail: gisele. crispe@gmail.com 
e Cultura (CDB) against the Catholics for the Right to Decide (CDD). The goal of the action is to remove the term "catholic" from the corporate name of the $C D D$, arguing that CDD's defense of sexual and reproductive rights would be in disagreement with the fundamentals of Catholicism. Two dimensions of neoconservatism are discussed: the reactive juridification and its dissemination through the media and social networks (economy of performance). The data used are documents of the judicial process, initiated in 2018, and the historical repercussion of the court decision in favor of the $C D B$ published in the social networks of the entities and in the media, in October and November 2020. The article concludes that the lawsuit is part of a broader context of attacks on human rights and democracy itself and reveals the disputes within Catholicism. It also concludes that, although the performance of Catholicism has contributed to the maintenance of conservative structures along Brazilian history, there are elements that differentiate the contemporary politicalreligious performance in the field of Catholicism.

Keywords Neoconservatism. Reactive Juridification. Media performance. Catholicisms. Sexual and reproductive rights.

Pesquisas de pelo menos as últimas três décadas têm chamado a atenção para as formas de investimento das religiões na esfera pública (BURITY, 2015; ButLER et al., 2011; CAsanova, 1994; CAmurÇa, 2019; Montero, 2018). Na verdade, especialmente as religiões dominantes, como o Cristianismo, no caso do Ocidente, tiveram historicamente forte presença pública, seja como parte das instituições do Estado e das organizações e movimentos da sociedade civil. O que se busca mostrar agora é a forma contemporânea desses investimentos políticos, destacando seus agentes, arenas de atuação, estratégias e narrativas, a partir da análise de um caso concreto de embate entre duas organizações católicas.

Na região da América Latina e Caribe tem havido ênfase na atuação de grupos evangélicos conservadores, dado seu considerável crescimento não apenas em número de fiéis como também em poder social, político e econômico (ALMEIDA, 2017; CamurÇa, 2020; Carranza, 2020; Guadalupe, 2019; SEmÁn, 2019), em disputa direta com a hegemonia católica. Pesquisadores como Rodrigo Coppe Caldeira e Rodrigo Toniol, no entanto, têm chamado a atenção para o fato de que esse deslocamento do foco de análise tem deixado de contemplar a atuação política conservadora do campo católico. Em artigo que circulou para além do âmbito acadêmico, os autores lembram, no caso do Brasil, da atuação dos movimentos católicos leigos desde a década de 1920, que se mobilizaram na reação "às forças pluralizantes da 
sociedade brasileira" que ficaram mais evidentes no início da histórica republicana (CAldeira; Toniol, 2020).

Emerson Silveira também chamou a atenção para o fato de que esses movimentos leigos foram incentivados por "altas esferas eclesiásticas [que] viram a necessidade de empreender diversas estratégias para 'recatolicizar' o Estado e a sociedade", depois do advento do Estado laico com a carta constitucional de 1891 (Silveira, 2015, p. 936). Os movimentos antimodernos de "restauração católica" gestados no início do século fariam parte da base de apoio ao golpe militar de 1964 e de sustentação da ditadura civil-militar que se seguiu nos 20 anos seguintes ${ }^{1}$. A união da direita católica a outros movimentos de sustentação do regime autoritário é bem condensada no nome de um de seus principais grupos, a Tradição, Família e Propriedade (TFP).

Se, no entanto, a atuação histórica do catolicismo contribuiu para a manutenção das estruturas conservadoras na sociedade brasileira e em outros países da região, há indícios de que o momento atual traz elementos que diferenciam a atividade político-religiosa no campo do catolicismo, relacionados a uma série de mudanças de contexto. Entre eles destacamos a perda de fiéis católicos para as igrejas evangélicas ${ }^{2}$ e as conquistas democráticas e relacionadas aos direitos humanos nas últimas décadas.

Nesse cenário, externamente, podemos observar uma aliança entre grupos católicos e evangélicos conservadores na manutenção de uma ordem moral ameaçada por direitos conquistados na segunda metade do século XX, em especial os direitos das mulheres e da população LGBTQI+. Essa aliança desloca alguns dos alvos dos grupos católicos conservadores gestados no início da República. O Centro Dom Vidal e sua revista A Ordem, por exemplo, tinha o objetivo, como aponta Silveira, de "defender a Igreja contra o liberalismo, o comunismo e o protestantismo, mormente por meio da apologia da fé católica” (SilveirA, 2015, p. 936). Já a união de católicos e evangélicos em algumas pautas nos últimos anos, ainda utilizando a retórica anticomunista, entre outras, faz parte da base que permitiu a chegada ao poder do bolsonarismo e a manutenção de um governo que se apresenta como representante de Deus e protetor do que vem sendo chamado de "Nação Cristã".

1 Vale lembrar, no entanto, que parte significativa da direção da Conferência dos Bispos do Brasil (CNBB) tornou-se opositora à ditadura civil-militar, com inúmeras manifestações públicas nesse sentido.

2 De acordo com o Censo de 2010 (IBGE), o número de fiéis católicos diminuiu quase 10\% em relação ao censo anterior, saindo de $73,6 \%$ para $64,6 \%$, enquanto os evangélicos cresceram $15,4 \%$ para $22,2 \%$ no mesmo período. 
Internamente, observa-se um movimento para "recristianizar o catolicismo" (CALDEIRA; Toniol, 2020) contra os ventos modernizantes trazidos pelo Concílio Vaticano II (1962-1965) e, mais recentemente, contra as atitudes ambíguas em relação a questões sociais, ambientais e de gênero apresentadas no pontificado do Papa Francisco. A pauta de "recristianização do catolicismo" expõe, de um lado, as mudanças e tensões no interior do próprio campo. De outro, tentativas de agentes católicos conservadores de homogeneizar o catolicismo a partir da defesa de verdades fundamentais que precisariam ser restauradas e preservadas.

Pois é sobre os agentes, arenas, estratégias e narrativas do conservadorismo católico da atualidade que discutimos neste artigo, a partir da análise da ação judicial do Centro Dom Bosco de Fé e Cultura (CDB), uma associação de leigos católicos fundada em 2016, contra outra associação formada por leigas, Católicas pelo Direito de Decidir (CDD), constituída no Brasil desde 1993, bem como seus desdobramentos na mídia e nas redes sociais. A ação, iniciada em 2018, tem o objetivo de proibir o uso do termo "católicas" no nome e nas atividades da instituição, com base no argumento de que as ações da entidade em defesa dos direitos sexuais e reprodutivos das mulheres vão contra os fundamentos do catolicismo.

Recusada em primeira instância por ilegitimidade do CDB para ingressar com esse tipo de ação, o Tribunal de Justiça do estado de São Paulo (TJ-SP) reverteu a sentença em segunda instância, em outubro de 2020, condenando CDD a retirar o termo "católicas" de seu estatuto. Apesar da sentença favorável ao CDB, no momento da finalização deste artigo, o TJ-SP admitiu os recursos especial e extraordinário apresentados por Católicas pelo Direito de Decidir, o que significa que seu julgamento passou para os tribunais superiores, respectivamente, o Superior Tribunal de Justiça (STJ) e o Supremo Tribunal Federal (STF), arena cada vez mais comum de regulação de direitos no Brasil.

A análise se centrará em três tipos de dados: documentos do processo judicial, repercussão da ação nas redes sociais do Centro Dom Bosco e dossiê organizado por Católicas pelo Direito de Decidir com a repercussão do caso nas mídias. É preciso destacar que duas autoras deste artigo fazem parte da CDD - o que permitiu acesso aos dados e um olhar, pegando emprestado uma perspectiva teórico-metodológica da antropologia urbana, "de perto e de dentro" (MAGNANI, 2002) - e que a terceira autora integra uma organização da sociedade civil que apoiou publicamente CDD neste caso. Por outro lado, ainda referenciando a Magnani, o distanciamento do olhar promovido no momento da análise permite uma reflexão estrutural sobre a atuação do neoconservadorismo católico. As três autoras fazem parte do Grupo de Estudos sobre Gênero, Religião e Política (GREPO) localizado na Pontifícia Univer- 
sidade Católica de São Paulo (PUC-SP) e desenvolvem suas pesquisas a partir das interrelações entre as ciências sociais, a ciência da religião e os estudos de gênero.

Como ponto de partida teórico, situamos a ação do CDB contra CDD naquilo que alguns autores vêm chamando de neoconservadorismo (VAGGIONE; MACHADO; BIROLI, 2020; LACERDA, 2019). O termo caracteriza uma nova forma de articulação de elementos e atores em torno de uma agenda reativa "antigênero" " "pró-família". Pensando no contexto latino-americano, Juan Marco Vaggione, Maria das Dores Campos Machado e Flávia Biroli destacam cinco dimensões do neoconservadorismo, que, apesar das diferenças e tensões internas, constituiu-se como um projeto compartilhado de agentes do campo conservador em oposição aos movimentos feministas e LGBTQI+ e que ganhou maior força aglutinadora e com popularidade nos anos 2000, a partir de uma batalha contra o que foi configurado como "ideologia de gênero"3.

A primeira dimensão são as alianças e afinidades entre diferentes setores. No campo religioso, as alianças se dão sobretudo entre católicos e evangélicos, diferentemente de períodos anteriores uma vez que, no geral, os evangélicos foram avessos aos movimentos ecumênicos da segunda metade do século XX. Mas as alianças se referem também aos setores religiosos com outros atores do campo conservador, como empresários, proprietários de terra, ultraliberais, políticos da extrema direita e militares. A segunda dimensão é a juridificação da moralidade. A juridificação tem o objetivo de limitar por meio do sistema de justiça o que pode ser considerado como direitos humanos (retirando de seu escopo os direitos sexuais e reprodutivos), estendê-los (como o "direito do nascituro") 4 e disputar seus significados (como liberdade de expressão, liberdade religiosa e liberdade de crença), utilizando para isso sua própria gramática.

A terceira dimensão é que o neoconservadorismo atua em contextos democráticos, apropriando-se de estratégias e instrumentos utilizados por defensores

3 Rogério Diniz Junqueira define "ideologia de gênero" como um sintagma neológico que emergiu no Vaticano, adquiriu centralidade no ativismo religioso e se constituiu como "um artefato retórico e persuasivo em torno do qual reorganizar seu discurso e desencadear novas estratégias de mobilização política e intervenção na arena pública" (JunqueIRA, 2018, p. 451). O termo foi eficaz para reunir atores transnacionais e "contribuiu para catalisar estratégias de poder que investem na mobilização da ordem moral e no revigoramento de visões de mundo tradicionalistas" (JUNQUEIRA, 2018, p. 452), categorizando os estudos de gênero e os movimentos de defesa de direitos das mulheres e da população LGBTQI+ como "grupos radicais" que, "por meio de discursos envolventes sobre a promoção da igualdade e o questionamento dos estereótipos, promoveriam a disseminação e imposição ideológica de um termo novo, perigoso e impreciso: o gender/gênero" (JUNQUEIRA, 2018, p. 453).

4 No Brasil, têm sido discutidos no Congresso Nacional projetos de lei que visam instituir o Estatuto do Nascituro desde 2005. Em 2021, a Casa Civil abriu uma consulta pública para debater uma minuta de projeto de lei que visa instituir o Dia Nacional do Nascituro e de Conscientização sobre os Riscos do Aborto, a ser comemorado anualmente no dia 8 de outubro. 
de direitos para influenciar as políticas públicas, com a instituição de partidos políticos, frentes parlamentares, organizações da sociedade civil, muitos deles de viés confessional. Embora esses movimentos ameacem a própria democracia e direitos conquistados por grupos vulnerabilizados, defendem sua participação pública com base na prerrogativa democrática e na estratégia de chamar de "ideológicos" os movimentos feministas e LGBTQI+, que atuariam contra uma moral que se pretende universal.

A quarta dimensão é o caráter transnacional do neoconservadorismo, com a realização de uma série de eventos e conferências regionais e internacionais, campanhas (como \#ConMisHijosNoTeMetas), a incidência em órgãos multilaterais como a Organização dos Estados Americanos (OEA) e a Organização das Nações Unidas (ONU), o recebimento de recursos oriundos de outros países para a defesa da moral religiosa, além da influência crescente da agenda cultural e das instituições da direita cristã estadunidense nos países da América Latina. A quinta dimensão é a relação entre neoconservadorismo e neoliberalismo, ambos colocando a família (vale dizer, a família heteronormativa e patriarcal) no centro da concepção de sociedade e a necessidade de protegê-la diante das ameaças advindas das conquistas de direitos pelos grupos vulnerabilizados, num contexto de crise econômica e social. De acordo com Wendy Brown (2019), ainda que a partir de razões distintas, os neoconservadores pela moral e os neoliberais pela economia têm na promoção dos valores familiares um dos pontos de convergência centrais.

A partir da análise da ação do Centro Dom Bosco contra as Católicas pelo Direito de Decidir, acrescentamos uma sexta dimensão que temos observado ${ }^{5}$ ser fundamental para o entendimento do neoconservadorismo: o manejo competente da mídia tradicional, da internet e das redes sociais, num contexto crescente de segmentação do consumo de mídia (Brown, 2019, p. 14) e de uma economia de mídia baseada no modelo das grandes plataformas digitais (INTERVozes, 2017). As ações judiciais são acompanhadas, de um lado, por uma grande repercussão nos canais de comunicação dos próprios agentes que acionam a justiça. Por outro lado, a escolha dos alvos e das pautas a serem judicializadas tem o potencial de ganhar uma grande repercussão pública. Assim, a ação judicial prolonga a discussão para

5 No GREPO, temos estudado de que forma a noção de "ideologia de gênero" nasce na Igreja Católica, é tratada nos documentos do papado de Francisco e como esse sintagma se dissemina e se populariza no Brasil a partir da atuação de sacerdotes com grande força midiática, no projeto de pesquisa "Feminismo e religião: uma análise do pensamento do Papa Francisco sobre a “ideologia de gênero”, apoiado pelo CNPq. 
além dos tribunais, fazendo da mídia outro lócus de questionamentos e de disputas sobre a própria ideia de direitos humanos.

A ação judicial apresenta algumas dimensões do neoconservadorismo que analisaremos a partir de agora. A observação deste caso nos permite compreender como dimensões do neoconservadorismo se articulam em embates que são considerados "batalhas" de uma guerra em curso. No caso analisado, a juridificação reativa se combina com a performance midiática na defesa da moralidade católica que se sente ameaçada, no incentivo a que novos agentes se engajem na reação e na tentativa de desarticular os sujeitos que lutam por direitos - inclusive dentro do campo religioso - em nome de uma suposta moral universal e de uma suposta verdade.

\section{CENTRO DOM BOSCO E A AÇÃO CONTRA CATÓLICAS PELO DIREITO DE DECIDIR}

O início desse processo se deu em julho de 2018. Os antecedentes que o motivaram remetem à Arguição de Descumprimento de Preceito Fundamental (ADPF) número 442 que foi apresentada pelo Partido Socialismo e Liberdade (PSOL) ao STF em março de 2017. O texto, que contou com a assessoria do Instituto de Bioética Anis, uma organização feminista, versava sobre a contrariedade dos dispositivos 124 e 126 do Código Penal, que criminalizam a interrupção voluntária da gravidez, com os direitos fundamentais previstos na Constituição Federal, tais como a igualdade, a liberdade, a saúde e os direitos reprodutivos. A ADPF pedia, assim, a descriminalização do aborto em qualquer circunstância até a $12^{\mathrm{a}}$ semana de gestação.

A arguição contou com um número recorde de pedidos de ingresso de Amicus Curiae $^{6}$ de acordo com levantamento realizado pela pesquisadora Eloísa Machado7. Em abril de 2018, a ministra Rosa Weber, relatora da ADPF, convocou audiências públicas para ouvir a sociedade civil sobre o tema. Dentre 187 inscrições, incluindo especialistas de diferentes áreas, foram selecionadas 45 representações para sustentar oralmente seus argumentos perante o STF, entre elas Católicas pelo Direito de Decidir, a única organização que, desde uma autodeclaração católica ${ }^{8}$, sustentava argumentos favoráveis à ADPF. As demais organizações e entidades

6 Amicus Curiae, termo latino que designa Amigo da Corte, se refere à atuação de terceiros a fim de apresentar ao tribunal elementos a serem considerados no julgamento de determinado processo, foi instituída no Brasil em 1999.

7 Disponível em https://www.conjur.com.br/2018-mar-20/adpf-discute-aborto-bate-recorde-amici-curiae-supremo. Acesso em 14 de abril de 2021.

8 Outras organizações e lideranças se apresentaram desde sua perspectiva religiosa favoráveis à ADPF, caso da pastora luterana Lusmarina. 
católicas apresentaram-se de forma oposta, caso da União dos Juristas Católicos de São Paulo (UJUCASP) e da Conferência Nacional dos Bispos do Brasil (CNBB).

É a partir desse momento que o Centro Dom Bosco de Fé e Cultura - uma associação jovem não apenas em tempo de existência, menos de dois anos à época, mas também em idade de seus componentes - entra em cena na arena judicial e midiática para impedir que a CDD utilizasse o nome "católicas" ao apresentar-se publicamente em favor da descriminalização e legalização do aborto. Em live ${ }^{9}$ realizada para comemorar o resultado em segunda instância que lhes foi favorável, uma das subscritoras da ação, a atual deputada federal Chris Tonietto (PL-RJ), ressalta que a motivação imediata para a ação ${ }^{10}$ foi justamente essa. A própria apresentação da ação faz referência à ADPF 442. A ação tinha por objetivo impedir, por vias judiciais, que o termo "católicas" fosse utilizado por CDD, não apenas na referida audiência pública, mas excluído de seu estatuto social. Além disso, pleiteava o pagamento das custas do processo e uma multa diária de R $\$$ 1.000,oo (mil reais) em caso de descumprimento da decisão.

O pedido judicial anexa documentos oficiais da hierarquia católica, publicações de sites católicos e até comentários de leitores para sustentar os argumentos. O primeiro anexo é uma nota da CNBB de 2008 na qual afirma que Católicas pelo Direito de Decidir não fala pela Igreja Católica ${ }^{11}$. Outro anexo traz uma publicação do blog do professor e apresentador Felipe de Aquino hospedado no site da Canção Nova, associação internacional privada de fiéis ligados à Renovação Carismática Católica $^{12}$. O texto de Dom Redovino Rizzardo, bispo de Dourados/MS, também faz referência à nota da CNBB, ampliando a interpretação de que não só CDD não representaria a Igreja Católica como afirmando a posição de que ela não poderia ser considerada uma organização católica. Na sequência do texto, são apresentados cinco comentários de leitores publicados no blog à época ${ }^{13}$, saudando a posição do bispo.

9 A live se realizou no dia 27 de outubro de 2020, quando foi publicizada a decisão por dois veículos especializados: Migalhas e Jota. Disponível em https://www.youtube.com/watch?v=EIbIKokkk fM\&list=PLEuNTNnNBFWjK5mPJ1iwAVJD-HXa2Ls6C\&index=14/. Acesso em 14 de abril de 2021.

10 Ação Declaratória com Pedido Liminar, processo $n^{0}$ 1071628-96.2018.8.26.0100, inscrita na $2^{\mathrm{a}}$ Câmara de Direito Privado do Tribunal de Justiça de São Paulo (TJ-SP).

11 Todos os anos, desde 1961, é realizada a Campanha da Fraternidade durante o período da quaresma. A cada ano é escolhido um problema social a ser refletido pelos fiéis. Em 2008 o tema foi Fraternidade e defesa da vida, e o lema Escolhe, pois, a vida. A nota foi produzida por ocasião das polêmicas geradas em torno da compreensão do início da vida e a liberdade de escolha das mulheres que decidem pela interrupção voluntária da gravidez.

12 https://blog.cancaonova.com/felipeaquino/2008/o2/18/voce-sabe-o-que-sao-catolicas-pelo-direito-de-decidir/ Acesso em 14 de abril de 2021

13 No anexo apresentado ao STJ, com impressão datada de 11/07/2018, os cinco comentários aparecem com data de 18 ou 19/02/2008. Na página do blog disponibilizada em abril de 2021 não constam comentários na publicação. 
O terceiro anexo é um testemunho dado ao site católico Aletea em 2013 por representantes da Santa Sé na ONU que, na ocasião da eleição do Papa Francisco, participavam da $57^{\mathrm{a}}$ sessão da Comissão da Condição da Mulher. Segundo relatam, foram interpelados por uma integrante de Católicas pelo Direito de Decidir do México, que questionava o lugar das mulheres dentro da Igreja e os abusos sexuais cometidos por membros da hierarquia. O questionamento é abordado no testemunho como evidente contraste com o entusiasmo dos demais católicos presentes com a eleição do novo Papa.

O conteúdo desses documentos converge para a narrativa, utilizada tanto na petição quanto nos eventos em plataformas midiáticas digitais, de que CDD não é "verdadeiramente" católica e, portanto, não faz jus ao nome que carrega. Por sua posição contrária a da hierarquia católica em relação ao aborto, o uso do termo "católicas" seria abusivo e com o intuito de causar confusão. Há, portanto, uma dupla disputa de narrativa - legitimidade do discurso (a defesa do aborto legal) e do próprio agente (quem poderia ou não se apresentar publicamente como católico).

Nesse processo, também é perceptível a alimentação mútua de conteúdo: de um lado, o processo judicial é alimentado por conteúdos midiáticos, de outro o processo fornece conteúdo para as performances midiáticas posteriores que serão desenvolvidas nas mídias e redes sociais do $\mathrm{CDB}$, assim como para as matérias jornalísticas produzidas pelas mídias tradicionais. A escolha dos materiais por parte do CDB para referendar a ação, nos sugere, assim, a conjugação das esferas judicial e midiática na atuação da entidade, não apenas enquanto estratégia, mas como as próprias arenas de disputa.

O recurso a uma noção de "verdade" como revelada por Deus, e portanto inquestionável e imutável, não é uma novidade dentro do catolicismo. Textos bíblicos são utilizados, a partir de uma leitura fundamentalista, para referendar essa compreensão. É o caso da afirmação que encontramos no Evangelho de João: "Conhecereis a verdade e ela vos libertará!" (Jó 8, 32). Como afirmam Carranza e Pereira:

Na proposta apologética do CDB a tradição católica é acionada para afirmar o cristianismo como sendo absoluto e imutável o que tornar-se-á em cristandade quando tido como a base constitutiva, moral e ética, da sociedade, inclusive das sexualidades e da produtividade humana (CARranza; Pereira, 2020).

Também não é novo o combate ao que, a partir dessa noção de "verdade" e da tradição cristã, é considerado como "falso". O confronto da TFP com as Comu- 
nidades Eclesiais de Base (CEBs) e a Teologia da Libertação partia desse mesmo princípio de que as últimas não eram "verdadeiramente católicas" e portanto seriam uma ameaça ao catolicismo. Na publicação "As CEBs ... das quais muito se fala, pouco se conhece - A TFP as descreve como são”, de 1982, Plínio Correa de Oliveira apresenta as CEBs e a Teologia da Libertação como perigos ao verdadeiro catolicismo, como violentas e como uma tentativa de penetração do comunismo na Igreja Católica.

Contudo, muito distante de uma realidade monolítica e imutável, a história da Igreja Católica demonstra o quanto ela é permeada por tensões, conflitos e mudanças. Como destaca Mainwaring, "as ações da Igreja refletem escolhas de valores e lutas políticas dentro da Igreja, qualquer modelo particular de igreja protege alguns interesses, mas à custa de outros" (MAINwARING, 2004, p. 40). Demonstra a história, ainda, que o catolicismo tem lidado com as dissonâncias internas muito mais com processos de assimilação do que de ruptura.

Essa compreensão de uma incompatibilidade da autodenominação de "católicas" da organização Católicas pelo Direito de Decidir com aquilo que a Igreja Católica Apostólica Romana enquanto instituição defende é largamente explorada no texto da ação. O texto faz referência ainda ao acordo estabelecido entre a Santa Sé e a República Federativa do Brasil (DECRETo 7.107/20104), afirmando que seria um desrespeito a este a continuidade do uso do nome "católicas".

Em declaração apresentada em 7 de agosto de 2018, em resposta ao juiz que pediu comprovante de legitimidade, o CDB sustenta que "a existência do Autor se funda também na possibilidade de atuar não em nome da Santa Igreja, mas sim de forma legítima contra ações flagrantemente opostas aos seus ensinamentos", buscando no Código de Direito Canônico guarida para sua afirmação. Mais uma vez a mídia entra em cena como "prova”. O CDB apresenta no processo matéria no jornal O Globo que tratava das audiências públicas convocadas pelo STF a respeito da ADPF 442 e citava Católicas pelo Direito de Decidir como uma das organizações oradoras. A matéria é apresentada para reforçar a argumentação de que a CDD faria uso publicamente do nome "católicas", o que seria "indevido", "abusivo" e "com a finalidade de causar confusão".

O CDB buscou também na história do Direito brasileiro argumentos para sua ação. É dessa forma que cita processo de 1949 que proibiu a Igreja Católica Apostólica Brasileira de utilizar em seus cultos vestes e liturgias semelhantes

14 Disponível em: https://www2.camara.leg.br/legin/fed/decret/2010/decreto-7107-11-fevereiro-2010-602309-norma-pe.html. Acesso em 14 de abril de 2021. 
às da Igreja Católica Apostólica Romana. O uso do termo "Católica”, no entanto, permaneceu, apesar de questionamentos do Consultor Geral da República e de magistrados de que a escolha do nome, do culto e dos ritos tinha "o objetivo de mistificar e confundir". Na ocasião, o único voto dissidente apontava para a inadequação da justiça de decidir assuntos internos da igreja, considerando que "não é lícito que essas Igrejas recorram ao prestígio do poder para resolver seus cismas, para dominar suas dissidências" (GiumbelLI, 2020).

Apesar de mobilizado como jurisprudência, o caso guarda muitas diferenças com o atual. A primeira delas diz respeito ao próprio conteúdo que se questionava como legítimo. A Igreja Católica Apostólica Brasileira disputava judicialmente o direito de se utilizar da denominação Católica, tendo finalidade, ritos e atuação análoga à Igreja Católica Apostólica Romana, que por quatro séculos gozou do estatuto de religião oficial do Estado. No caso atual, CDD não busca disputar o uso do nome com a Igreja Católica, nem possui atuação análoga à da instituição Católica, antes se declara publicamente como organização civil de adeptas da religião católica e não enquanto a própria religião. Um segundo ponto destoante se refere ao caráter mesmo das organizações envolvidas. Se em 1949 era a própria Igreja Católica Romana quem requeria a prerrogativa sobre a denominação "Católica", aqui trata-se de uma organização civil leiga questionando a legitimidade de outra de mesmo caráter em sua autodenominação.

A questão da legitimidade do Centro Dom Bosco como proponente foi um dos pontos explorados pela defesa de Católicas pelo Direito de Decidir. A defesa argumentou que o Centro Dom Bosco, assim como CDD, se constitui como uma organização da sociedade civil, composta por leigos sem vínculos institucionais com a Igreja, não lhe cabendo a prerrogativa de determinar ou questionar a validade da auto proclamação de fé de outras pessoas ou grupos. Alega ainda decadência da reclamação, ou seja, uma vez que CDD possui registro enquanto organização da sociedade civil no Brasil "sem maiores questionamentos a respeito de sua denominação pelo registrador e nem por ninguém, dentro dos 25 anos de atividades da Ré", não caberia contestação neste momento.

Acolhendo o entendimento de que não havia por parte do Centro Dom Bosco legitimidade para ajuizar em nome da Igreja Católica e tampouco havia dolo causado por parte de CDD, o juiz da primeira instância extinguiu a ação por ilegitimidade ativa sem adentrar no mérito. O CDB seguiu, sem fazer alarde, com seu propósito de impedir que a organização se autodenomine como "católica" apelando 
à segunda instância ${ }^{15}$ para que fosse reconhecida sua legitimidade como autora e julgado o mérito. Em requerimento datado de 10 de dezembro de 2018, o CDB inclui seu interesse na produção de prova oral por meio de três testemunhas, todas elas católicas com atuação na área do direito ${ }^{16}$.

No acórdão ${ }^{17}$ de 20 de outubro de 2020, os desembargadores reformaram a sentença do juiz da primeira instância, reconhecendo a legitimidade ativa do autor, afastando a alegação de decadência da defesa e considerando o mérito da ação procedente. Determinaram, assim, a abstenção do uso da expressão "católicas", devendo esta ser excluída do estatuto social da organização; o pagamento de multa diária de mil reais, sem indicação de limite ou destino do valor, e o pagamento de verbas honorárias no valor de três mil reais. Novo acórdão de 12 de dezembro de 2020, em resposta a um embargo de declaração da CDD, reafirma o anterior, estabelece o limite da multa a cem mil reais e seu destino ao autor da ação.

No entendimento dos desembargadores a finalidade e a atuação de CDD "revelam PÚBLICA E NOTÓRIA incompatibilidade com os valores adotados pela associação autora e pela Igreja Católica de modo geral - Violação à moral e bons costumes, havendo evidente contrariedade ao bem e interesses públicos”. Afirmam ainda que "além de ferir notoriamente o Direito Canônico, se traduz inegável desserviço à sociedade, não interessando a quem quer que seja a existência de grupo com nome que não corresponda a sua autêntica finalidade"18.

Argumentos e materiais utilizados pelos desembargadores para reforçar o que apontam como "notória contrariedade da requerida em relação à Igreja Católica", se aproximam daqueles apresentados pelos autores. Dentre outros materiais, encontramos trechos de um vídeo do padre Paulo Ricardo denominado "A resposta católica”. Figura de referência para o CDB, Paulo Ricardo ganhou proeminência na cena pública a partir dos anos 2010, por meio de uma série de ações na mídia. Além de programa na TV Canção Nova, possui um site com cursos, vídeos e artigos, perfis nas redes sociais Facebook, Twitter e Instagram e um canal no Youtube que contava, em abril de 2021, com mais de 1,1 milhão de inscritos. Citam também

15 A segunda instância é composta por três desembargadores que devem revisar a primeira sentença do juiz singular. Uma vez entrando em consenso, os desembargadores publicam a decisão.

16 Paulo Henrique Cremoneze, advogado, pós-graduado em Teologia e vice-presidente da UJUCASP, Monsenhor Osvaldo de Almeida Neves, graduado em Direito, membro da Secretaria de Estado da Santa Sé, tendo trabalhado por 25 anos na Cidade Estado do Vaticano, e Padre Ricardo de Barros Marques, doutor em Direito Canônico pela Pontifícia Universidade Lateranense, Roma, e diretor do Tribunal Eclesiástico da Diocese de Santos.

17 É chamada de acórdão a decisão de um colegiado de desembargadores ou ministros.

18 Apelação Cível no $1071628-96.2018 .8$.26.0100 - Voto n ${ }^{0} 38978$ 
conteúdos dos sites católicos Aletea, Agência Católica de Informações (ACI) e Canção Nova, todos veículos de mídia do campo conservador católico.

São citados ainda trechos de homilia do Papa João Paulo II de 1980 e das Encíclicas Evangelium Vitae e Fratelli Tutti e o Código do Direito Canônico, em articulação com leis brasileiras, como a Lei nº 6.015/73, que dispõe sobre registros públicos, a Lei de Introdução às Normas do Direito Brasileiro, o Código Civil, a Constituição Federal e o Código de Processo Civil, além do Acordo entre o governo brasileiro e a Santa Sé relativo ao Estatuto Jurídico da Igreja Católica no Brasil ${ }^{19}$.

Como se vê a mídia esteve presente em todo o processo, ora como conteúdo da argumentação das partes ou dos juízes, ora como o próprio espaço de atuação para divulgar, amplificar e debater o conteúdo do processo. Outra evidência do papel fundamental exercido pela mídia neste caso é o fato do acórdão ter vindo a conhecimento de CDD, parte no processo, ao mesmo tempo que do público em geral, por meio de duas matérias publicadas em veículos especializados em direito e políticas públicas que repercutiram a decisão ${ }^{20}$. A partir dessas duas notas se iniciou um amplo debate nos meios jurídico e midiático, abrangendo tanto veículos tradicionais e de grande circulação, quanto mídias alternativas e redes sociais digitais, como veremos adiante.

\section{JURIDIFICAÇÃO REATIVA E A DISPUTA EM TORNO DE "VERDADE” E “LEGITIMIDADE”}

O processo narrado acima se insere em um contexto de atuação de agentes religiosos católicos conservadores no campo do direito, por meio da formulação de projetos de lei e da ação no judiciário, que se intensificou a partir dos anos 1990, com incentivo do Vaticano. O próprio Centro Dom Bosco afirma a importância dessa arena. Na ação contra a CDD, os autores declaram que "a atuação eficaz do Poder Judiciário é a única capaz de restabelecer a justiça e punir tal postura levada a efeito pela parte demandada" ${ }^{21}$. Antes da ação contra a CDD, a entidade com apenas dois anos de existência já havia ajuizado outras ações ${ }^{22}$ na perspectiva de "defesa da fé católica”. Dentre elas, a ação civil pública contra a produtora Porta dos Fundos e a plataforma de streaming Netflix, pela produção e veiculação do

19 Apelação Cível no 1071628-96.2018.8.26.0100 - Voto nº 38978.

20 Disponível em: https://www.jota.info/justica/tjsp-proibe-uso-catolicas-organizacao-pro-aborto-27102020 Acesso em 14 de abril de 2021.

21 Centro Dom Bosco de Fé e Cultura. Ação Declaratória com Pedido Liminar, processo n⿳0 1071628 96.2018.8.26.0100, inscrita na ${ }^{\mathrm{a}}$ Câmara de Direito Privado do Tribunal de Justiça de São Paulo (TJ-SP).

22 De acordo com busca textual no site JusBrasil foram encontrados 10 processos movidos pelo Centro Dom Bosco. Disponível em https://www.jusbrasil.com.br/busca?q=associa\%C3\%A7\% C3\%A30+centro+dom+bosco+de+f\%C3\%A9+e+cultura Acesso em 17 de abril de 2021. 
especial de Natal "A última tentação de Cristo", em que Jesus é retratado como homossexual. O grupo humorístico havia sofrido outras duas ações pela retirada de vídeos de seu canal do YouTube pelo CDB.

Nesse caso, a ofensa indicada é a Deus e à fé católica e, por extensão, à cultura brasileira e todo o Ocidente que, nas palavras do presidente da entidade, Pedro Affonseca, "foi fundado, construído, desenvolvido pela fé católica também”. Além da retirada do episódio do ar, o CDB solicitou no processo uma multa indenizatória de dois milhões de reais, o que indica, como no caso da ação contra a CDD, que o processo judicial visa também favorecer economicamente o autor das ações e inviabilizar a atividades de determinados grupos pela via econômica, deslocando tempo, energia e recursos financeiros e humanos das organizações de suas atividades cotidianas para o processo. A veiculação do programa chegou a ser suspensa pelo Tribunal de Justiça do Rio de Janeiro em dezembro de 2019, mas o vídeo foi liberado por uma liminar concedida pelo STF em janeiro de 2020, decisão confirmada pela Suprema Corte em 3 de novembro de 2020, com base na liberdade de expressão e no argumento de que o vídeo fazia uma crítica, por meio de sátira, a elementos caros ao cristianismo, mas que não ofendia a honra dos cristãos nem incitava violência contra grupos religiosos.

Se, como mostra Juan Marco Vaggione, já no início do século XX foram formadas associações profissionais ou organizações de advogados católicos "com o propósito de defender uma cultura católica ameaçada pela laicidade" (VAGGIONE, 2020, p. 66), nas últimas décadas do século passado, em contextos democráticos e laicos e de pluralismo religioso, a atuação de agentes católicos no campo dos direitos se intensificou e se modificou. As ações passaram a visar a restauração de uma "ordem moral ameaçada" pelas conquistas, também feitas a partir do campo do direito, de movimentos feministas e LGBTQI+, que incluíram os direitos sexuais e reprodutivos no rol dos direitos humanos.

Não à toa o $\mathrm{CDB}$ se apresenta como "uma família que reza, estuda e defende a fé". Mais do que isso, a associação de leigos católicos visa restaurar uma ordem moral ameaçada não apenas na arena pública, mas dentro do próprio catolicismo. A apresentação da entidade enfatiza que "estudamos a doutrina bimilenar a fim de resgatar o que foi perdido por causa do modernismo e das diversas infiltrações na estrutura eclesiástica”23.

Ao processo de restauração moral ameaçada por direitos conquistados, Vaggione dá o nome de "juridificação reativa", definida como o "uso do direito por

23 Disponível em: http://centrodombosco.org/\# Acesso em 17 de abril de 2021. 
parte de atores religiosos e seculares em defesa dos princípios morais que esses consideram violados pelas demandas dos movimentos feministas e LGBTQI, empregando diferentes argumentos e estratégias" (VAGGIONE, 2020, p. 42). A juridificação reativa considera o direito como arena e como estratégia. $\mathrm{O}$ direito como arena significa que é no e pelo direito que as principais disputas em torno das políticas sexuais e de gênero são travadas. De um lado da disputa, estão os movimentos de mulheres e LGBTQI+, que questionaram a matriz moralista e moralizante do direito que por muito tempo associou moral católica ao direito secular; de outro, o Vaticano e seus agentes religiosos e leigos, que defendem a atuação religiosamente motivada no campo do direito secular para assegurar uma ordem moral ameaçada ${ }^{24}$. O direito, assim, é visto em sua função simbólica de legitimar ou deslegitimar visões de mundo, práticas e moralidades por meio da lei e da jurisprudência.

Já o direito como estratégia observa a "maquinaria legal conservadora" (VAGGIONE, 2020, p. 43), composta por uma série de agentes: o Vaticano e outras instâncias da hierarquia católica; hierarquias evangélicas; advogados confessionais e associações de juristas e advogados confessionais; faculdades de direito, principalmente as ligadas às universidades católicas e evangélicas; professores e pesquisadores do direito; políticos, partidos políticos e frentes parlamentares cristãs; funcionários públicos que priorizam suas crenças religiosas; grupos de pais e mães; e organizações não-governamentais que se chamam de "pró-vida" e "pró-família", como podemos caracterizar o Centro Dom Bosco.

Essa maquinaria se articula em torno de alguns argumentos centrais: a "cidadanização do feto" a partir de leis mais rígidas contra o aborto; a defesa da ideia de "família natural" como único modelo possível e legítimo, incluindo o casamento heterosexual, a maternidade como destino biológico das mulheres, a desigualdade natural entre homens e mulheres a partir de diferenças biológicas e o direito da família sobre os filhos, ameaçado pela "ideologia de gênero"; e a ressignificação da liberdade religiosa, que deixa de ser vinculada à defesa da diversidade religiosa frente ao poder das religiões majoritárias e passa a ser disputada como defesa do direito de cristãos frente a conquistas em termos de direitos sexuais e reprodutivos.

Ao observar a atuação dos grupos religiosos católicos conservadores na arena do direito, é importante chamar a atenção para as arenas e estratégias em que católicos e evangélicos se encontram. É importante, então, observar não só como

24 O Vaticano incentiva a atuação de religiosos e leigos católicos na sociedade em defesa da moral religiosa. Em 2002, por exemplo, ofereceu reconhecimento canônico à União Internacional de Juristas Católicos. 
os documentos do Vaticano (como o Compêndio da Doutrina Social da Igreja ${ }^{25}$ e o Discurso do Papa João Paulo II aos juristas católicos ${ }^{26}$ ) incentivam a atuação de religiosos e leigos na esfera jurídica, como que pontos de contato e diferenças podem haver com teologias evangélicas como a Teologia do Domínio e de que forma esses dois grupos se aproximam quando se trata da atuação em uma pauta específica: a reação aos direitos sexuais e reprodutivos ${ }^{27}$. O conceito de juridificação reativa, portanto, nos ajuda a entender a ação do CDB contra as Católicas pelo Direito de Decidir dentro de um contexto mais amplo de atuação de setores religiosos cristãos para a manutenção de sua moralidade, em articulação com setores conservadores não religiosos. A direita cristã é, no entendimento de Marina Lacerda (2019), o ator central do neoconservadorismo.

No entanto, a ação contra a CDD possui elementos que anunciam uma nova estratégia: uma ação não apenas contra os direitos sexuais e reprodutivos, mas que busca definir quais são os agentes legítimos e não legítimos para atuar nessa arena em disputa. Como vimos na seção anterior, a ação judicial movida pelo Centro Dom Bosco contra a CDD não visava contestar os direitos sexuais e reprodutivos defendidos pela organização, mas o direito de uma associação que defende tais direitos usar o termo Católicas em seu nome. Este caso não é isolado. Católicas pelo Direito de Decidir do Peru ${ }^{28}$ sofre investida semelhante para retirada de "católicas" de seu nome por parte do Centro Tomás Moro, formado por advogados católicos, cujo lema, em direção semelhante ao do CDB, é "Cristianizando el derecho, cristianizando la sociedad".

Evidencia-se assim a contraposição não apenas às pautas defendidas pelas organizações demandadas, mas à existência mesma dessas organizações. Em ambos os casos se observa por parte dos grupos proponentes sua auto afirmação como legítimos defensores de uma "verdadeira fé" ao passo que contestam a legitimidade da autodeclaração como católicas das organizações que demandam. A semelhança dos princípios e estratégia de juridificação não é fortuita, ao contrário, evidencia um modus operandi do campo neoconservador e seu caráter transnacional.

25 Disponível em: https://www.vatican.va/roman_curia/pontifical_councils/justpeace/documents/ rc_pc_justpeace_doc_20060526_compendio-dott-soc_po.html\#MISS\%C3\%83O\%20DA\%20 IGREJA\%2OE\%2ODOUTRINA\%20SOCIAL. Acesso em 14 de abril de 2021.

26 Disponível em: http://www.vatican.va/content/john-paul-ii/pt/speeches/1980/december/documents/hf_jp-ii_spe_19801206_giuristi-cattolici.html. Acesso em 14 de abril de 2021.

27 A Associação de Juristas Evangélicos (Anajure) foi fundada em 2012 e desde então vem atuando no Congresso Nacional, no Executivo e no Judiciário em defesa da concepção neoconservadora de liberdade religiosa e de expressão, da moral cristã e sua concepção de "vida" e de "família". Sobre a Anajure, ver: https://apublica.org/2019/o6/associacao-de-juristas-evangelicos-fundada-por-damares-alves-amplia-lobby-no-governo/ Acesso em 18 de abril de 2021.

28 Católicas pelo Direito de Decidir está presente em 12 países da América Latina e do Caribe, incluindo o Brasil. 


\section{REPERCUSSÃO DA AÇÃO NAS REDES SOCIAIS: RETÓRICA DA PERDA E PERFORIMANCE DA VITÓRIA}

A repercussão da decisão judicial em segunda instância, que reconhece a legitimidade do Centro Dom Bosco no processo e o mérito da ação, foi analisada por Olívia Bandeira e Rafaela Marques (2020) como produzindo uma "economia da performance". Por economia da performance as autoras entendem o modo como transaciona-se visibilidade e legitimidade para mobilizar a identidade religiosa. Importante não é só o resultado da ação, mas como ela é performatizada nas mídias e redes sociais. No dia seguinte à publicação do acórdão com a decisão do TJ-SP, integrantes do CDB fizeram uma live que durou pouco mais de duas horas com o título "Vão ter que tirar o nome de “católicas'!". Misturando orações com comentários acerca do processo judicial e do histórico da CDD, a live foi vista no dia e nas semanas que se seguiram por pouco mais de 50 mil pessoas.

O título já anunciava o conteúdo do discurso apresentado, que visava comemorar uma "vitória" em uma das batalhas de uma guerra que estaria em curso e engajar novos agentes no combate, para que atuem em todas as esferas da sociedade, incluindo o sistema judiciário. De um lado da guerra estariam os "verdadeiros católicos", assim reconhecidos pela sentença da justiça, e de outro os "inimigos da fé" que, neste caso, seriam as Católicas pelo Direito de Decidir. As integrantes da CDD são chamadas de "grupelho abortista", "pilantras feministas", "Coisas pelo Direito de Decidir". O presidente da entidade afirmou também que elas, "as coisas", seriam parte de um grupo de "pseudo-católicas infiltradas na igreja". A performance, assim, apresenta com outras palavras aquilo que motivou a ação judicial: proibir um grupo de católicas feministas de se autodeclararem como parte do conjunto de católicos. No entanto, diferentemente da ação judicial, na live são utilizadas palavras que alimentam o discurso de ódio contra um grupo específico - católicas feministas e, por decorrência, feministas de um modo geral - que tem sido parte da gramática de grupos neoconservadores nas redes sociais.

Este tipo de vídeo é comum no canal de Youtube do Centro Dom Bosco, que transforma em "vitória" atos, muitas vezes isolados ou produzidos pelo próprio CDB, buscando ampliar o significado dos mesmos por meio da performance midiática. Assim, por exemplo, a homilia de um padre da paróquia Nossa Senhora de Lourdes contra a Campanha da Fraternidade Ecumênica de 2021 foi publicada sob o título "Padre enterra de vez a Campanha da Fraternidade!". Com mais de 724 mil visualizações em abril de 2021, o vídeo ajudou a disseminar a hashtag \#boicotacf2021. O tema da campanha, desenvolvido pelas igrejas que fazem parte 
do Conselho Nacional de Igrejas Cristãs do Brasil (CONIC) ${ }^{29}$ e que foi saudado pelo Papa Francisco ${ }^{30}$, é "Fraternidade e diálogo: Compromisso de Amor". Repudia o racismo, a misoginia e outras formas de violência que aprofundam a "cultura de ódio", em nome de uma "cultura do amor". Em vídeo publicado no canal de Youtube do CDB em 17 de março de 2021, intitulado "Conheça o Kit gay da Campanha da Fraternidade" ${ }^{11}$, o apresentador afirmou que "infiltrados" no CONIC e na Cúpula da CNBB "incluíram a ideologia de gênero e demais pautas extremistas identitárias no texto-base”. Usando estratégias típicas da desinformação, que é apresentar informações de forma descontextualizada com o objetivo de produzir determinados efeitos políticos (InTERvozes, 2019), o apresentador destaca fala da pastora luterana Romi Bencke, secretária-geral do CONIC, sobre a campanha, faz uma leitura descontextualizada de seus materiais e sugere aos católicos que não contribuam financeiramente com a ação. Neste caso também, a performance midiática do neoconservadorismo religioso promoveu discurso de ódio e incentivou ameaças pelas redes sociais, sendo que o alvo principal foi exatamente a pastora Romi ${ }^{32}$.

Em outro vídeo, o CDB comemora como "Vitória da Igreja" a não celebração da missa em homenagem ao Dia da Consciência Negra na Paróquia do Sagrado Coração de Jesus, no bairro da Glória, Zona Sul do Rio de Janeiro, em 20 de novembro de 2020. O vídeo é intitulado “A missa 'afro' foi cancelada e proibida para sempre! Deo gratias!” e tinha mais de 41 mil visualizações em abril de $2021^{33}$. Um ano antes, a missa do Dia da Consciência Negra na paróquia foi perturbada por integrantes do Centro Dom Bosco, que fizeram orações em voz alta para atrapalhar a missa. Na ocasião, cinco pessoas foram indiciadas por intolerância religiosa. Em 2020, o CDB voltou a fazer barulho nas redes sociais sobre o assunto, conclamando

29 As igrejas membro do CONIC são: Aliança de Batistas do Brasil - ABB, Igreja Católica Apostólica Romana (ICAR), por meio da CNBB, Igreja Episcopal Anglicana do Brasil (IEAB), Igreja Evangélica de Confissão Luterana no Brasil (IECLB) e Igreja Presbiteriana Unida (IPU). A Campanha da Fraternidade Ecumênica 2021 é a quinta realizada neste formato. A Comissão responsável é formada por representantes das igrejas-membro do CONIC, além da Igreja Betesda de São Paulo, como igreja observadora, e o Centro Ecumênico de Serviços à Evangelização e à Educação Popular (Ceseep), como membro fraterno.

30 Mensagem do Papa Francisco para a Campanha da Fraternidade Ecumênica 2021 disponível em: https://www.cnbb.org.br/papa-francisco-envia-mensagem-ao-brasil-para-a-campanha-da-fraternidade-ecumenica-2021/ . Acesso em 18 de abril 2021.

31 Disponível em: https://www.youtube.com/watch?v=dVeSI5jAxWc\&t=64s Acesso em 18 de abril de 2021.

32 Neste caso também, diversas organizações da sociedade civil, igrejas e lideranças religiosas manifestaram seu apoio público à pastora Romi Bencke e ao CONIC. Disponível em: https:// reformapolitica.org.br/2021/o2/10/solidariedade-a-pastora-romi-bencke-e-ao-conic/. Acesso em 18 de abril de 2021.

33 Disponível em: https:/g1.globo.com/rj/rio-de-janeiro/noticia/2020/11/20/missa-em-homenagem-ao-dia-da-consciencia-negra-no-rio-e-cancelada-um-ano-apos-ato-de-intolerancia-religiosa-no-templo.ghtml Acesso em 18 de abril de 2021. 
fiéis a fazerem jejum para impedir que a missa fosse realizada e a se mobilizarem na porta da igreja caso não fosse cancelada.

A economia da performance desses grupos articula, assim, ações judiciais, ações e mobilizações realizadas nas ruas e a amplificação desses eventos por meio das redes sociais. Ritualizam, em múltiplas esferas, a batalha do bem contra o mal, por meio de uma série de performances de vitória.

Comum na Teologia do Domínio que pode ser vista em parte do mundo pentecostal brasileiro, [a batalha espiritual] vem sendo utilizada também por grupos católicos conservadores. Essa batalha (...) deve se dar por meio da ação nas várias esferas da sociedade, como o sistema judiciário, o poder legislativo e a mídia. A noção de que há uma guerra por ser enfrentada se apoia na retórica do medo, em que o discurso é utilizado para gerar o sentimento de insegurança, de que a ordem moral e social já está ameaçada e que poderá se tornar pior caso não se faça alguma coisa. A defesa dos direitos reprodutivos feita pelas Católicas pelo Direito de Decidir, entre outras organizações feministas, é nessa chave apresentada como porta de entrada para uma dissolução completa da sociedade. Nas palavras da deputada Tonietto, "aborto é o último reduto moral. Se o aborto for permitido, tudo vem a reboque, tudo vem junto, porque se uma nação permite que o assassinato intraulterino seja aprovado, o que mais não vai aprovar? Pedofilia e toda sorte de crimes. Por isso não podemos descansar e se for preciso ajuizar quantos processos forem necessários" (BANDEIRA; MARQUes, 2020).

As ações judiciais, assim, estão atreladas a uma performance que também apela ao medo de uma suposta ordem moral ameaçada. É aquilo que Christina Vital da Cunha vem qualificando como "retórica da perda", que pode ser considerada uma "tática discursiva articulada por diferentes lideranças sociais e políticas (dentre elas, religiosas) baseada em um imperativo: o retorno da ordem, da previsibilidade, da segurança, de uma unidade (ainda que imaginada)"34. O contexto de crise econômica e social propicia a alimentação do medo social por meio do discurso de que, no final das contas, é a família de cada cristão que está ameaçada. Já a solução está nas guerras travadas em todos os setores da sociedade (justiça, executivo,

34 Ver: "Apoio evangélico a Bolsonaro é marcado por uma grande volatilidade“, entrevista concedida por Christina Vital da Cunha ao site do Instituto Humanitas Unisinos. Disponível em: http://www.ihu.unisinos.br/159-noticias/entrevistas/592934-apoio-evangelico-a-bolsonaro-e-marcado-por-uma-grande-volatilidade-entrevista-especial-com-christina-vital-da-cunha. Acesso em 18 de abril de 2021. 
legislativo, escola, mídia) por uma "maioria" (a ideia de "Nação Cristã”) contra os direitos conquistados pelas "minorias". Em nome dessa "moral ressentida", nas palavras de Wendy Brown (2019), trava-se uma batalha contra os direitos humanos, a pluralidade (como no ataque à missa pelo Dia da Consciência Negra) e a própria democracia, valendo-se inclusive de ameaças e discurso de ódio. Nessa batalha, o inimigo não é apenas externo, mas está “infiltrado" dentro do próprio catolicismo.

\section{MEDIATIZAÇÃO RELIGIOSA E EMBATES DISCURSIVOS NA ARENA PÚBLICA}

Se o Centro Dom Bosco inclui ações nas redes sociais como parte fundamental de sua estratégia, é preciso destacar também que são ações com potencial de grande repercussão nas mídias tradicionais. Isso ajuda a explicar a visibilidade que adquiriu um grupo com poucos anos de existência. A ação do CDB contra as Católicas pelo Direito de Decidir teve grande repercussão midiática, assim como a ação que o grupo moveu contra o Porta dos Fundos. Assim, a organização busca se colocar como ator importante nas disputas públicas sobre os direitos humanos no Brasil e no interior do próprio catolicismo.

O dossiê organizado por CDD com o material jornalístico presente na mídia digital (não incluídos jornais exclusivamente impressos, rádios e TVs) totaliza 77 notícias ou artigos de opinião sobre a ação, em veículos do Brasil e de outros países, entre os dias 27 de outubro, dia seguinte à publicação do acórdão, e 23 de novembro de 2020, intervalo de menos de 30 dias. A ação também gerou manifestações públicas e notas de apoio de uma série de organizações da sociedade civil e juristas, publicadas nos sites das entidades e nas redes sociais. Além disso, houve a reação de pesquisadores da área do direito e das ciências sociais e da religião em forma de artigos publicados no período.

A cobertura da mídia nos apresenta pistas sobre os temas que a repercussão midiática da atuação dos grupos neoconservadores por meio da legislação e do sistema de justiça inserem na arena de disputas sobre os direitos humanos, em especial os direitos sexuais e reprodutivos, e a laicidade do Estado. Dividimos as mídias analisadas em seis tipos: mídia tradicional (compreendida como os veículos dos conglomerados que tradicionalmente concentram a audiência e a publicidade do setor, conforme o Monitoramento da Propriedade da Mídia35); mídia independente do campo progressista (aquela que não faz parte dos grandes conglomerados

35 O Monitoramento da Propriedade da Mídia é um projeto de pesquisa criado pela Repórteres Sem Fronteiras Alemanha e que analisou a concentração da mídia em diversos países do mundo. No Brasil, foi realizado em parceria com o Intervozes - Coletivo Brasil de Comunicação Social. Disponível em: http://brazil.mom-rsf.org/br/. Acesso em 14 de abril de 2021. 
e se declara como progressista); mídia independente do campo conservador (que também não fazem parte dos grandes grupos de mídia e se declaram conservadoras); mídia especializada em direito, leis e políticas públicas; mídia acadêmica; e mídia de organizações da sociedade civil.

\section{A PAUTA DO ABORTO E A HETEROGENEIDADE DO CATOLICISMO}

Os veículos da mídia tradicional, no geral, apresentaram uma cobertura bem contextualizada sobre o tema. A Folha de S. Paulo, jornal impresso de maior tiragem no Brasil ${ }^{36}$, fez uma matéria extensa sobre o caso $^{37}$, que foi reproduzida em todo ou em partes em outros veículos ${ }^{38}$. Também deu espaço para artigos de opinião e publicou um editorial que fala do tema. É preciso destacar que o veículo defende o aborto legal, como mostra a pesquisa "Vozes Silenciadas Direitos Sexuais e Direitos Reprodutivos"39. A menor parte das matérias da mídia tradicional se coloca contra a pauta das Católicas pelo Direito de Decidir. A crítica pode ser sutil e aparecer, por exemplo, por meio de imagens, como na matéria da Gazeta do Povo de $27 / 10 / 2020^{40}$, que traz a foto dos braços de uma mulher vestida como enfermeira ou médica com um feto de papel na palma das mãos (imagem recorrente em meios de comunicação do campo conservador que destacam o feto ou mesmo uma mulher em estágio avançado de gravidez, reforçando a ideia de "cultura de morte"). No geral, as imagens destacam, de forma diferente, as católicas em manifestações nas ruas segurando cartazes em defesa do Estado laico, dos direitos sexuais e reprodutivos e contra "fundamentalismos".

36 Disponível em: http://brazil.mom-rsf.org/br/. Acesso em 14 de abril de 2021.

37 Disponível em: https://www1.folha.uol.com.br/cotidiano/2020/10/justica-proibe-catolicas-pelo-direito-de-decidir-de-usar-catolicas-no-nome.shtml Acesso em 14 de abril de 2021.

38 Entre os veículos que reproduziram a matéria da Folha estão o portal Mix Vale em 27/10/2020 (https://www.mixvale.com.br/2020/10/27/justica-proibe-catolicas-pelo-direito-de-decidir-de-usar-catolicas-no-nome/), o jornal O Tempo em 27/10/2020 (https://www.otempo.com.br/brasil/justica-de-sp-veta-catolicas-pelo-direito-de-decidir-de-usar-catolicas-no-nome-1.2404912) e o Diário do Nordeste em 28/10/2020 (https://diariodonordeste.verdesmares.com.br/seu-direito/ong-pro-aborto-catolicas-pelo-direito-de-decidir-nao-pode-usar-catolicas-no-nome-decide-justica-1.3004629). Acesso em 14 de abril de 2021.

39 A pesquisa mostra que, em geral, a mídia tradicional respeita o aborto legal, mas não relaciona o tema aos direitos sexuais e direitos reprodutivos e à cultura do estupro, além de não tratar o tema a partir de uma perspectiva interseccional. Analisando a cobertura sobre o caso da criança de dez anos que, em agosto de 2020, foi impedida de abortar no estado do Espírito Santo, tendo que se deslocar até o estado de Pernambuco para exercer seu direito legal, e as novas regras sobre o aborto publicadas pelo Ministério da Saúde do governo de Jair Bolsonaro em 2020, o estudo identificou que, apesar da cobertura extensa, os veículos de mídia costumam silenciar sobre o papel dos ministérios da Saúde e da Mulher, Família e Direitos Humanos. Dados preliminares publicados em: https://www.cartacapital.com.br/blogs/intervozes/imprensa-nao-condena-aborto-mas-blinda-governo/ Acesso em 14 de abril de 2021.

40 Disponível em: https://www.gazetadopovo.com.br/vida-e-cidadania/breves/ong-pro-aborto-proibida-justica-usar-catolicas-nome/?ref=botao-fechar-sticky Acesso em 14 de abril de 2021. 
Mesmo assim, várias matérias enfatizam sem muito espaço ao contraditório alguns dos argumentos apresentados pelos desembargadores, já resumidos na primeira parte deste texto, que indicam o que está em jogo na ação contra a CDD. Entre eles, o argumento de que a prática da ONG seria contrária aos valores (Cláudia, 28/10/2020 ${ }^{41}$, Universa UOL, 28/10/2020 ${ }^{42}$ ) ou aos fundamentos da Igreja Católica (G1, 27/10/202043), promovendo "pautas antagônicas ao catolicismo" (Folha de S. Paulo, 27/10/202044; Deutsche Welle, 28/10/202045); de que violaria "a moral e os bons costumes" (Jovem Pan, 27/10/202046; Estadão, 28/10/202047; Cláudia, 28/20/2020 ${ }^{48}$ ) e o bem e o interesse público (Jovem Pan, 27/10/2020 49 ; Cláudia, 28/20/2020 ${ }^{50}$ ); e ainda de que a decisão não violaria a liberdade de expressão (Estadão, 28/10/2020 ${ }^{51}$; Universa UOL, 28/10/2020 ${ }^{52}$; SBT, 28/10/2020 ${ }^{53}$ ). Algumas matérias citam também declaração do Centro Dom Bosco de que a CDD seria uma "fraude" (Metrópoles, 27/10/202054; Universa UOL, 28/10/2020 55 ; Estadão, 28/10/2020 ${ }^{56}$ ), defenderia "o homicídio de bebês no útero

41 Disponível em: https://claudia.abril.com.br/noticias/aborto-catolica-ong/ Acesso em 14 de abril de 2021.

42 Disponível em: https://www.uol.com.br/universa/noticias/redacao/2020/10/28/catolicas-pelo-direito-de-decidir.htm Acesso em 14 de abril de 2021.

43 Disponível em: https://g1.globo.com/sp/sao-paulo/noticia/2020/10/27/tribunal-de-justica-de-sp-proibe-ong-catolicas-pelo-direito-de-decidir-que-defende-aborto-legal-de-usar-catolicas-no-nome.ghtml Acesso em 14 de abril de 2021.

44 Disponível em: https://www1.folha.uol.com.br/cotidiano/2020/10/justica-proibe-catolicas-pelo-direito-de-decidir-de-usar-catolicas-no-nome.shtml Acesso em 14 de abril de 2021.

45 Disponível em: https://www.dw.com/pt-br/agora-existe-um-dono-do-nome-cat\%C3\%B3licas/a-55427101 Acesso em 14 de abril de 2021.

46 Disponível em: https://jovempan.com.br/noticias/brasil/justica-proibe-grupo-religioso-pro-aborto-de-usar-termo-catolicas-no-nome.html Acesso em 14 de abril de 2021.

47 Disponível em: https://politica.estadao.com.br/blogs/fausto-macedo/desembargadores-proibem-organizacao-de-religiosas-feministas-e-pro-aborto-de-usar-catolicas-no-nome/ Acesso em 14 de abril de 2021.

48 Disponível em: https://claudia.abril.com.br/noticias/aborto-catolica-ong/ Acesso em 14 de abril de 2021.

49 Disponível em: https://jovempan.com.br/noticias/brasil/justica-proibe-grupo-religioso-pro-aborto-de-usar-termo-catolicas-no-nome.html Acesso em 14 de abril de 2021.

50 Disponível em: https://claudia.abril.com.br/noticias/aborto-catolica-ong/ Acesso em 14 de abril de 2021.

51 Disponível em: https://politica.estadao.com.br/blogs/fausto-macedo/desembargadores-proibem-organizacao-de-religiosas-feministas-e-pro-aborto-de-usar-catolicas-no-nome/ Acesso em 14 de abril de 2021.

52 Disponível em: https://www.uol.com.br/universa/noticias/redacao/2020/10/28/catolicas-pelo-direito-de-decidir.htm Acesso em 14 de abril de 2021.

53 Disponível em: https://www.sbtnews.com.br/noticia/justica/152518-tribunal-proibe-ong-feminista-de-usar-catolicas-no-nome Acesso em 14 de abril de 2021.

54 Disponível em: https://www.metropoles.com/brasil/justica-de-sp-proibe-organizacao-feminista-de-usar-catolicas-no-nome Acesso em 14 de abril de 2021.

55 Disponível em: https://www.uol.com.br/universa/noticias/redacao/2020/10/28/catolicas-pelo-direito-de-decidir.htm Acesso em 14 de abril de 2021.

56 Disponível em: https://politica.estadao.com.br/blogs/fausto-macedo/desembargadores-proibem-organizacao-de-religiosas-feministas-e-pro-aborto-de-usar-catolicas-no-nome/ Acesso em 14 de abril de 2021. 
materno" (Folha de S. Paulo, 27/10/202057; Universa UOL, 28/10/2020 ${ }^{58}$, Deutsche Welle, 28/10/202059), além de ser "anticatólica" (Estadão, 28/10/2020 ${ }^{60}$ ) ou tentar implementar uma agenda "progressista e anticatólica" (Jovem Pan, 27/10/2020 61; Cláudia, 28/20/2020 ${ }^{62}$ ) "em meio aos católicos" (G1, 27/10/2020 $\left.{ }^{63}\right)$.

A maior parte das matérias deu voz às Católicas pelo Direito de Decidir por meio de nota publicada pela ONG em suas redes sociais. A posição da CDD sobre o tema foi aprofundada em poucas matérias, devido à cautela inicial da entidade em se manifestar sobre uma decisão a que teve conhecimento pela mídia. Foi o caso de matéria na revista Cláudia (28/20/2020 64), veículo do Grupo Abril voltado ao público feminino, que apresentou os argumentos da CDD sobre a necessidade de se defender o aborto nos casos previstos em lei e o direito das mulheres serem atendidas pelo serviço público, de forma segura. Também apresentou o argumento de que "mesmo no campo do catolicismo, com sua história e doutrina, encontramos elementos suficientes para dizer que uma mulher pode recorrer a um aborto e continuar sendo católica. Ela não precisa abandonar a sua fé porque tomou essa decisão. Pelo contrário, ela pode recorrer à fé para se decidir”.

Já a versão brasileira do jornal alemão Deutsche Welle publicou uma entrevista com Rosângela Talib ${ }^{65}$, membro do Conselho Institucional da entidade. Talib diz que, embora sempre tenham sido questionadas pelo fato de serem católicas e defenderem os direitos sexuais e reprodutivos como direitos humanos, era a primeira vez que eram interpeladas judicialmente. Também se mostrou surpresa com a ação voltada contra a entidade e não contra as pautas defendidas por ela, como salientamos anteriormente, ao mostrarmos a novidade que a ação inaugura em relação aos debates sobre direitos humanos, uma vez que se volta não apenas

57 Disponível em: https://www1.folha.uol.com.br/cotidiano/2020/10/justica-proibe-catolicas-pelo-direito-de-decidir-de-usar-catolicas-no-nome.shtml Acesso em 14 de abril de 2021.

58 Disponível em: https://www.uol.com.br/universa/noticias/redacao/2020/10/28/catolicas-pelo-direito-de-decidir.htm Acesso em 14 de abril de 2021.

59 Disponível em: https://www.dw.com/pt-br/agora-existe-um-dono-do-nome-cat\%C3\%B3licas/a-55427101 Acesso em 14 de abril de 2021.

60 Disponível em: https://politica.estadao.com.br/blogs/fausto-macedo/desembargadores-proibem-organizacao-de-religiosas-feministas-e-pro-aborto-de-usar-catolicas-no-nome/ Acesso em 14 de abril de 2021.

61 Disponível em: https://jovempan.com.br/noticias/brasil/justica-proibe-grupo-religioso-pro-aborto-de-usar-termo-catolicas-no-nome.html Acesso em 14 de abril de 2021.

62 Disponível em: https://claudia.abril.com.br/noticias/aborto-catolica-ong/ Acesso em 14 de abril de 2021.

63 Disponível em: https://g1.globo.com/sp/sao-paulo/noticia/2020/10/27/tribunal-de-justica-de-sp-proibe-ong-catolicas-pelo-direito-de-decidir-que-defende-aborto-legal-de-usar-catolicas-no-nome.ghtml Acesso em 14 de abril de 2021.

64 Disponível em: https://claudia.abril.com.br/noticias/aborto-catolica-ong/ Acesso em 14 de abril de 2021.

65 Disponível em: https://www.dw.com/pt-br/agora-existe-um-dono-do-nome-cat\%C3\%B3licas/a-55427101 Acesso em 14 de abril de 2021. 
a questionar quais são os direitos, mas quem é legítimo ou não para defendê-los. A psicóloga também chamou a atenção para a diferença entre o catolicismo como instituição e como prática de sua membresia. À pergunta "Afinal, a quem pertence o termo “católico'?”, Talib respondeu:

(...) nos espanta saber que agora existe um dono do nome católicas, né? Porque ao que sabemos católicos é o povo de Deus, todos os que foram batizados, fizeram a primeira comunhão e comungam como nós são católicos. Nunca fomos alijadas da Igreja. Não fomos excomungadas. Portanto, somos católicas, sim (Deutsche Welle, 28/10/2020 ${ }^{66}$ ).

O Portal Universa UOL, veículo do Grupo Folha também voltado ao público feminino, destacou que, embora o Papa Francisco condene o aborto, comparando a interrupção da gravidez à contratação de um "matador de aluguel", o assunto não é consenso na Igreja. Para isso, citou entrevista dada por Regina Jurkewicz ao portal Ecoa, em que a integrante de CDD questiona a doutrina da Igreja Católica.

Isso foi considerado a partir de 1860, quando o Papa declara que a vida é desde o momento da concepção e que tirar a vida em qualquer época é um homicídio, um pecado muito grave. Algo muito condenável. Mas esse posicionamento nem sempre foi assim. Santo Agostinho falava que, entre 40 a 80 dias, é que existe o que ele chamava de hominização, que é o momento que aquele ser que está ali, embrião ou feto, recebe a alma (Universa UOL, 28/10/2020 ${ }^{67}$ ).

A Folha de S. Paulo também mostrou de que forma o tema é visto de diferentes formas entre católicos. Em matéria já citada, depois de apresentar a posição contrária do Papa Francisco, apresentou os argumentos de alas progressistas do catolicismo: de que "a criminalização culpabiliza as mulheres e provoca mortes, especialmente de pobres e negras, e, portanto, os que são contra não estão preocupados em defender a vida”; de que a proibição impõe sofrimento, em especial às crianças vítimas de estupro; de que "o aborto é uma consequência de um problema

66 Disponível em: https://www.dw.com/pt-br/agora-existe-um-dono-do-nome-cat\%C3\%B3licas/a-55427101 Acesso em 14 de abril de 2021.

67 Disponível em: https://www.uol.com.br/universa/noticias/redacao/2020/10/28/catolicas-pelo-direito-de-decidir.htm Acesso em 14 de abril de 2021. 
anterior, que é o estupro"; e de que a morte por causa de abortos clandestinos seria parte de uma "teologia policialesca"68.

As matérias na mídia independente do campo progressista também situam o aborto no campo dos direitos. Citam que, na ausência de formas de interrupção da gravidez legais e seguras, muitas mulheres recorrem a procedimentos clandestinos que levam à morte (Rede Brasil Atual, 27/10/202069, Esquerda Diário, $28 / 10 / 2020^{70}$ ), sendo mulheres negras e indígenas as principais vítimas (Rede Brasil Atual, 27/10/2020 ${ }^{71}$ ). Também defendem a legitimidade de se afirmarem como católicas e feministas ao criticar a justiça de interferir na declaração religiosa das pessoas e entidades (Esquerda Diário, 28/10/2020 ${ }^{72}$, Diário da Causa Operária, 03/11/2020 73 ).

Dessa forma, podemos observar que a ação não apenas deu visibilidade à CDB e às disputas que o grupo visa inserir no debate público sobre o aborto, mas pautou na mídia tradicional e na mídia independente do campo progressista o tema a partir da ótica dos direitos sexuais e reprodutivos. No que se refere ao assunto, embora os argumentos dos desembargadores tenham sido pouco questionados, o aborto é apresentado como uma conquista das mulheres na esfera do direito.

Também deram visibilidade à heterogeneidade do catolicismo. Não à toa, o campo religioso conservador tem investido na produção de suas próprias mídias, como veremos a seguir, incluindo a mídia tradicional e progressista no rol dos inimigos a serem combatidos.

\section{AS MÍDIAS RELIGIOSAS CONSERVADORAS NA DISPUTA PELOS DIREITOS HUMANOS E PELA IMPOSIÇÃO DA IDEIA DE "VERDADE"}

As mídias independentes do campo conservador inseridas no dossiê adotam uma postura discursiva muito semelhante à da CDB na live citada na seção anterior. Destacamos, em primeiro lugar, como elas classificam as Católicas pelo Direito de

68 Disponível em: https://www1.folha.uol.com.br/cotidiano/2020/10/justica-proibe-catolicas-pelo-direito-de-decidir-de-usar-catolicas-no-nome.shtml Acesso em 14 de abril de 2021.

69 Disponível em: https://www.redebrasilatual.com.br/cidadania/2020/10/justica-catolicas-pelo-direito-de-decidir-aborto/ Acesso em 14 de abril de 2021.

70 Disponível em: https://www.esquerdadiario.com.br/Diana-Assuncao-repudia-censura-do-judiciario-ao-nome-da-ONG-Catolicas-pelo-Direito-de-Decidir Acesso em 14 de abril de 2021.

71 Disponível em: https://www.redebrasilatual.com.br/cidadania/2020/10/justica-catolicas-pelo-direito-de-decidir-aborto/ Acesso em 14 de abril de 2021.

72 Disponível em: https://www.esquerdadiario.com.br/Diana-Assuncao-repudia-censura-do-judiciario-ao-nome-da-ONG-Catolicas-pelo-Direito-de-Decidir Acesso em 14 de abril de 2021.

73 Disponível em: https://www.causaoperaria.org.br/direita-quer-censurar-catolicas-pelo-direito-de-decidir/ Acesso em 14 de abril de 2021. 
Decidir. A ONG é chamada de "ONG pró-aborto" (Estudos Nacionais, 27/10/202074; Pleno News, 28/10/2020 75 ), "ONG abortista” (ACI Digital, 28/10/2020 ${ }^{76}$, ACI Prensa, 29/10/2020 ${ }^{77}$ ) "associação religiosa pró-aborto" (Anna Ramalho, 27/10/2020 ${ }^{78}$ ) ou "associação de religiosas pró-aborto" (Templário de Maria, 27/10/202079), sem qualquer menção à luta por direitos das mulheres e pelos direitos sexuais e reprodutivos reconhecidos.

Em outros sites, a definição visa construir um discurso de que haveria verdadeiros e falsos católicos. O canal Direita.TV - cujo slogan é "O canal da direita realista, para você nunca mais precisar ligar a TV na sua vida!", tendo uma bandeira do Brasil como ícone - chama a CDD, desde o título, de "associação abortista". Já o CDB é chamado de "essa sim uma entidade católica" (27/10/2020) ${ }^{80}$. O mesmo faz o site Brasil Sem Medo que chama a CDD de "associação pró-aborto" e de "não-católicas pelo direito de decidir", enquanto define o CDB como "essa sim, católica" $(27 / 10 / 2020)^{81}$. O site Aleteia (28/10/2021) ${ }^{82}$ define a CDD como "não são católicas", "grupo de viés ideológico [que] não segue a doutrina da Igreja" e "organização que usa estrategicamente o termo 'católicas' para pregar ideologias e práticas que não são católicas”. Também frisa que seria uma “organização abortista”, estratégia também utilizada por outros sites, como o ACI Digital, que diz que a CDD internacional já gastou milhões de dólares na América Latina para "promover o aborto" ${ }^{3}$.

Evidenciando o caráter transnacional das estratégias e dos discursos das direitas cristãs, observamos também que a ação repercutiu em veículos de outros países. O site colombiano Razón Mas Fé, formado por católicos leigos com o

74 Disponível em: https://www.estudosnacionais.com/29607/ong-pro-aborto-nao-podera-mais-usar-o-termo-catolicas-em-seu-nome-determina-o-tj-sp\%E2\%81\%A3/ Acesso em 14 de abril de 2021.

75 Disponível em: https://pleno.news/fe/tj-proibe-ong-pro-aborto-de-usar-palavra-catolicas-no-nome.html Acesso em 14 de abril de 2021.

76 Disponível em: https://www.acidigital.com/noticias/justica-proibe-ong-abortista-de-usar-catolicas-no-nome-72747 Acesso em 14 de abril de 2021.

77 Disponível em: https://www.aciprensa.com/noticias/tribunal-prohibe-a-ong-catolicas-por-el-derecho-a-decidir-seguir-llamandose-catolicas-46929 Acesso em 14 de abril de 2021.

78 Disponível em: https://www.annaramalho.com.br/justica-proibe-associacao-religiosa-pro-aborto-de-usar-catolicas-no-nome/ Acesso em 14 de abril de 2021.

79 Disponível em: https://templariodemaria.com/justica-proibe-catolicas-pelo-direito-de-decidir-de-usar-catolicas-no-nome/?fbclid=IwARoe806VwNZEnmTgYs6kMWQcL7fxJM9lX8WFyO K50P2D7jWW5YMujRU1rrw Acesso em 14 de abril de 2021.

80 Disponível em: https://www.direita.tv/associacao-aborteira-proibida-catolicas-nome/ Acesso em 14 de abril de 2021.

81 Disponível em: https://brasilsemmedo.com/justica-decide-que-associacao-pro-aborto-nao-pode-usar-o-termo-catolicas-no-nome/ Acesso em 14 de abril de 2021.

82 Disponível em: https://pt.aleteia.org/2020/10/28/catolicas-pelo-direito-de-decidir-nao-sao-catolicas-e-justica-proibe-uso-do-termo/ Acesso em 14 de abril de 2021.

83 Disponível em: https://www.acidigital.com/noticias/justica-proibe-ong-abortista-de-usar-catolicas-no-nome-72747 Acesso em 14 de abril de 2021. 
objetivo de promover a "cultura da vida", define a CDD como "Las mal llamadas 'Católicas' por el Derecho a Decidir, una ONG feminista que por años, bajo el nombre de 'Católicas', el cual ya no podrán usar más, confundían a los Católicos con sus falsas proclamas contrarias a las enseñanzas de la Iglesia Católica” (29/10/2020) ${ }^{84}$. Já o site The Central Minnesota, da Diocese de St. Cloud (Minnesota/EUA), definiu a CDD como "grupo pró aborto" e reproduziu declarações do presidente do CDB nas redes sociais com ofensas à CDD (29/10/2020) ${ }^{85}$.

Assim, podemos perceber que a cobertura da mídia tradicional e da mídia do campo progressista não esconde e, muitas vezes, enfatiza, a heterogeneidade do catolicismo, enquanto a mídia do campo conservador busca ocultar a diversidade e pluralidade, enfatizando uma suposta unidade no catolicismo, que seria baseada numa verdade universal.

\section{AÇÃO CONTRA A CDD NO CONTEXTO DO NEOCONSERVADORISMO}

Outra pista importante que o dossiê nos permite observar é de que forma a ação judicial está inserida em um contexto mais amplo de reação conservadora aos direitos conquistados por grupos sociais, como as mulheres e os grupos LGBTQI+, e uma disputa mais geral pelos direitos humanos. Matéria já citada da Folha de S. Paulo (27/10/2020) ${ }^{86}$ e um editorial publicado dias depois (29/10/2020) ${ }^{87}$ insere a ação num contexto mais amplo de atuação do governo Bolsonaro contra os direitos sexuais e reprodutivos. Colocando-se à favor do aborto, que considera uma questão de saúde pública, critica as ações do governo Bolsonaro, entre elas o documento Estratégia Federal de Desenvolvimento para o Brasil (2020-2031) ${ }^{88}$, a assinatura da Declaração de Consenso de Genebra ${ }^{89}$, Portaria do Ministério da Saúde que

84 Disponível em: https://www.razonmasfe.com/actualidad/corte-prohibe-a-catolicas-aborto/ Acesso em 14 de abril de 2021.

85 Disponível em: https://thecentralminnesotacatholic.org/brazilian-judge-bans-catholic-from-name-of-pro-abortion-group/ Acesso em 14 de abril de 2021.

86 Disponível em: https://www1.folha.uol.com.br/cotidiano/2020/10/justica-proibe-catolicas-pelo-direito-de-decidir-de-usar-catolicas-no-nome.shtml Acesso em 14 de abril de 2021.

87 Disponível em: https://www1.folha.uol.com.br/opiniao/2020/10/cruzadas-antiaborto.shtml Acesso em 14 de abril de 2021.

88 Entre outras coisas, o texto incluiu como meta "promover o direito à vida, desde a concepção até a morte natural, observando os direitos do nascituro, por meio de políticas de paternidade responsável, planejamento familiar e atenção às gestantes". Decreto 10.531/2020. Disponível em: https://www.in.gov.br/en/web/dou/-/decreto-n-10.531-de-26-de-outubro-de-2020-285019495 . Acesso em 13 de abril de 2021.

89 Documento apresentado no dia 22 de outubro de 2020 pelo secretário de Saúde dos EUA, Alex Azar, e pelo secretário de Estado, Mike Pompeo, com a presença dos ministros brasileiros Ernesto Araújo (Ministério das Relações Exteriores) e Damares Alves (Ministério da Mulher, Família e Direitos Humanos). Além de EUA e Brasil, o documento conta com apoio de quase 30 países com governos conservadores, entre eles, Egito, Hungria, Indonésia e Uganda, e tem o objetivo de apresentar uma declaração política conjunta contra o aborto ("direito à vida") e em defesa da família heteronormativa. Disponível em: https:/www.gov.br/pt-br/noticias/ 
buscava constranger os médicos que realizam o procedimento ${ }^{90}$ e a tentativa do Ministério da Mulher, da Família e dos Direitos Humanos de intervir no procedimento de aborto de uma criança de 10 anos, fruto de estupro.

Veículos do campo progressista também colocaram a ação como parte de uma política mais ampla do Estado e, em especial, do governo Bolsonaro, contra o direito ao aborto legal (Rede Brasil Atual, 27/20/202091; Esquerda Diário, 28/10/202092; Causa Operária TV, 28/10/2020 93 ), visão que pouco circulou em outros veículos da mídia tradicional. Além de contextualizar as ações do governo, matéria na Rede Brasil Atual de 27/10/2020 94 reproduziu fala da pesquisadora feminista Débora Diniz no Twitter em que "avaliou que o parecer da Justiça é mais uma forma de ‘perseguição de um Estado Fanático”. Matéria da Causa Operária TV (28/10/2020)95 também chama pela "necessidade de entender que tipo de religiosidade é essa e que tipo de conservadorismo é esse", ao afirmar que CDB e entidades semelhantes criminalizam as mulheres enquanto defendem que "bandido bom é bandido morto".

$\mathrm{O}$ ataque aos direitos humanos e à democracia aparece também em artigos de opinião que foram publicados em diversos veículos no período. Nota ${ }^{96}$ assinada por mais de 100 entidades da sociedade civil expressou a preocupação com a violação das liberdades de expressão e associação. Para as entidades signatárias, a decisão corrobora "com práticas censórias que caminham na contramão das sociedades democráticas" e "abre um precedente jurídico e político muito perigoso" que afetam não só a CDD, mas todas as organizações da sociedade civil.

\section{LAICIDADE DO ESTADO}

Nesse contexto de ascensão do neoconservadorismo, algumas matérias, mas sobretudo artigos de opinião e as notas de apoio de organizações da sociedade civil, defendem o Estado laico. O editorial da Folha de S. Paulo de 29/10/2020 diz que “o

assistencia-social/2020/10/brasil-assina-declaracao-sobre-defesa-do-acesso-das-mulheres-a-promocao-da-saude. Acesso em 13 de abril de 2021.

90 Portaria 2.282 de 27 de agosto de 2020. Disponível em: https://www.in.gov.br/en/web/dou/-/ portaria-n-2.282-de-27-de-agosto-de-2020-274644814 Acesso em 13 de abril de 2021.

91 Disponível em: https://www.redebrasilatual.com.br/cidadania/2020/10/justica-catolicas-pelo-direito-de-decidir-aborto/ Acesso em 14 de abril de 2021.

92 Disponível em: https://www.esquerdadiario.com.br/Diana-Assuncao-repudia-censura-do-judiciario-ao-nome-da-ONG-Catolicas-pelo-Direito-de-Decidir Acesso em 14 de abril de 2021.

93 Disponível em: https://www.youtube.com/watch?v=Xz69LznoHDg\&ab_ channel=CausaOperariaTV Acesso em 14 de abril de 2021.

94 Disponível em: https://www.redebrasilatual.com.br/cidadania/2020/10/justica-catolicas-pelo-direito-de-decidir-aborto/ Acesso em 14 de abril de 2021.

95 Disponível em: https://www.youtube.com/watch?v=Xz69LznoHDg\&ab_ channel=CausaOperariaTV Acesso em 14 de abril de 2021.

96 https://abong.org.br/2020/10/29/nota-de-solidariedade-a-organizacao-catolicas-pelo-direito-de-decidir-e-em-defesa-da-liberdade-de-expressao-e-associacao-no-brasil/ 
cerco" ou a "cruzada antiaborto" chegou ao sistema de Justiça: "Beira o escárnio que uma corte judicial em um país laico se arrogue o direito de dirimir questões eclesiásticas, em violação à liberdade constitucional de associação"97. Questionamento sobre o uso do Direito Canônico aparece no portal G1 (27/10/2020) quando contextualiza que “o Direito Canônico, que é o conjunto de leis feitos ou adotados pelos líderes da Igreja Católica, pode ser aplicado no Brasil desde 2005 (...). No entanto, ainda não há posição consolidada sobre essa questão no direito brasileiro"98.

Interessante observar que na maioria das mídias especializadas em direito, leis e políticas públicas, as matérias não tenham abordado a laicidade do Estado nem questionado a citação de documentos da Igreja Católica e de lideranças religiosas na decisão do desembargador (Jota, 27/10/2020 ${ }^{99}$; Migalhas, 27/10/2020 ${ }^{100}$ ). Parecem, assim, naturalizar que uma decisão judicial acione indistintamente a legislação brasileira e documentos religiosos ou, mais do que isso, utilize documentos religiosos na interpretação das leis brasileiras.

A defesa da laicidade do Estado aparece, no entanto, em artigos de opinião publicados nesses veículos no período. Entre eles, artigo das pesquisadoras do direito Lígia Ziggiotti de Oliveira e Heloisa Fernandes Câmara, que afirmam que a "decisão não é condizente com a laicidade estatal e com a liberdade política previstas constitucional e internacionalmente" e que abre precedente "preocupante de autoritarismo estatal e fundamentalismo religioso". Afirmam ainda que o Estado laico deveria proteger as religiões e não "manifestar-se quanto às questões internas como preceitos e dogmas de cada manifestação. Ao dizer que há uma notória incompatibilidade, o Desembargador relator do caso excluiu diversas visões presentes dentro de uma mesma religião" (Jota, 31/10/2020) ${ }^{101}$.

\section{CONSIDERAÇ̃̃ES FINAIS}

O caso concreto que analisamos aqui se mostrou exemplar, ou mesmo paradigmático, das formas de atuação do neoconservadorismo político-religioso das últimas décadas, com foco no catolicismo. É possível verificar na atuação do

97 Disponível em: https://www1.folha.uol.com.br/opiniao/2020/10/cruzadas-antiaborto.shtml Acesso em 14 de abril de 2021.

98 Disponível em: https://g1.globo.com/sp/sao-paulo/noticia/2020/10/27/tribunal-de-justica-de-sp-proibe-ong-catolicas-pelo-direito-de-decidir-que-defende-aborto-legal-de-usar-catolicas-no-nome.ghtml Acesso em 14 de abril de 2021.

99 Disponível em: https://www.jota.info/paywall?redirect_to=//www.jota.info/justica/tjsp-proibe-uso-catolicas-organizacao-pro-aborto-27102020 Acesso em 14 de abril de 2021.

100Disponível em: https://migalhas.uol.com.br/quentes/335508/associacao-religiosa-pro-aborto-e-proibida-pela-justica-de-usar--catolicas--no-nome Acesso em 14 de abril de 2021.

101Disponível em: https://www.jota.info/paywall?redirect_to=//www.jota.info/opiniao-e-analise/ artigos/estado-guardiao-catolicismo-catolicas-pelo-direito-de-decidir-31102020 Acesso em 14 de abril de 2021. 
Centro Dom Bosco as cinco dimensões do neoconservadorismo observadas por Vaggione, Machado e Biroli (2020). Verificamos de outra parte elementos que nos sugerem uma sexta dimensão a ser acrescida que diz respeito à inter-relação das estratégias de juridificação reativa - o uso do direito como arena e como estratégia de disputa em torno, sobretudo, dos direitos sexuais e reprodutivos - com performances midiáticas.

A performatização das ações judiciais - sobretudo na retórica da "vitória" é favorecida por um cenário de fragmentação das mídias (BRown, 2019), com o advento das novas tecnologias de informação e comunicação. É favorecida também pelo modelo de negócios das grandes plataformas digitais (redes sociais, buscadores e plataformas de autopublicação de áudio e vídeo), que incentivam a publicação de uma diversidade de conteúdos, mas não promovem a pluralidade - no sentido da distribuição igualitária de poder para as diferentes vozes em atuação no debate público. Ao contrário, o modelo centrado na coleta e uso dos dados pessoais dos usuários e na automatização dos sistemas de recomendação acabam promovendo conteúdos “caça-cliques”, desinformativos e de discurso de ódio, estratégias discursivas presentes na análise das mídias do campo conservador.

Se, de um lado, as novas tecnologias da comunicação e informação se tornam não apenas ferramentas, mas arenas onde se ritualizam vitórias conquistadas no judiciário, de outro, as próprias mídias conservadoras são incorporadas aos processos judiciais, fornecendo conteúdos que dão sustentação aos mesmos. Essa dinâmica de interação entre a atuação litigante e performances midiáticas invocam o engajamento dos fiéis, em diversas dimensões. A primeira é a dimensão da batalha espiritual conforme mobilizada neste caso $^{102}$. Se, de um lado, são mobilizados sentimentos de medo frente a ameaças à ordem religiosa e social, de outro as performances de vitória ritualizam o triunfo do bem contra o mal, do certo contra o desviante, do verdadeiro contra o falso, reforçando a própria crença nessas polaridades. A batalha do bem contra o mal, neste caso, fornece a interpretação teológica que se encontra com a "moral ressentida" (BROwN, 2019), favorecendo um questionamento de valores que pareciam pacificados, como direitos humanos, liberdades, pluralidade e democracia.

A segunda dimensão é a afirmação da "verdade" única e imutável e que estaria presente apenas em uma religião (o Cristianismo) e em uma determinada concepção dessa religião, em oposição à pluralidade e diversidade no próprio

102A batalha espiritual nem sempre está ligada à moral conservadora e pode ser observada também na construção teológica de visões mais progressistas no interior do cristianismo (Bandeira, 2017). 
campo religioso. Utilizando categorias de acusação - como a ideia de "fraude" e de agente "infiltrado" - grupos como o CDB acionam de forma contemporânea o que grupos católicos do campo conservador já realizavam no século passado: a criação do inimigo dentro do próprio catolicismo. A própria ideia de "recristianizar o catolicismo" e "defender a fé" passa pelo pressuposto da existência de um cristianismo autêntico que precisa ser recuperado. Assim, não basta realizar litígios contra os direitos conquistados, mas é preciso calar os próprios agentes religiosos que defendem esses direitos. Associações como as Católicas pelo Direito de Decidir ameaçam uma das estratégias centrais dos movimentos "pró-vida" e "pró-família" que é apresentar o campo religioso cristão como homogêneo, invisibilizando tanto a heterogeneidade da visão dos crentes quando de concepções teológicas. Assim, o catolicismo é, ele próprio, um campo de disputas, como lembrou Giumbelli (2020). Ainda que o caso aqui estudado trate de um grupo católico, essa compreensão não é exclusividade do catolicismo conservador, mas comum ao neoconservadorismo cristão.

De outra parte, a própria disputa que se apresenta na cena pública é reveladora dessa diversidade que se quer ocultar ou controlar. Se a juridificação reativa se volta contra os direitos conquistados, é preciso destacar também as reações da sociedade civil e de parte da imprensa na garantia da manutenção de direitos e do Estado como seu guardião. Nesse sentido, as manifestações de apoio por parte de diferentes organizações da sociedade civil no campo progressista situam a ação contra a CDD não como um caso isolado, mas como voltada para todas as organizações da sociedade civil e à própria ideia de democracia, de direitos humanos e de liberdades fundamentais. Esses termos não são negados pelo discurso neoconservador, ao contrário, se tornam arenas nas quais disputam seus significados e valores atrelados.

A repercussão na mídia também situa a ação no contexto mais amplo de ascensão de governos conservadores em diferentes países da região. No caso do Brasil, um governo que tem entre católicos e evangélicos conservadores uma de suas bases de sustentação e que aciona a ideia de "Nação Cristã" na defesa de uma de suas principais pautas de atuação tanto nacional quanto internacionalmente: a família cristã heteronormativa e a defesa da vida desde a concepção, em oposição aos direitos sexuais e reprodutivos.

Por fim, o estudo deste caso particular suscita questões a serem aprofundadas em outros textos a respeito das relações estabelecidas entre religião e Estado no Brasil contemporâneo, e as formulações particulares que assume a laicidade no contexto brasileiro, assim como o processo de secularização da própria religião. 


\section{REFERÊNCIAS BIBLIOGRÁFICAS}

Almeida, Ronaldo. A onda quebrada: evangélicos e conservadorismo. Cadernos Pagu, Campinas, SP, n.50, 2017. Disponível em: https://periodicos.sbu.unicamp.br/ojs/ index.php/cadpagu/article/view/8650718. Acesso em: 18 de abril de 2021.

Bandeira, Olívia. O mundo da música gospel entre o sagrado e o secular: disputas e negociações em torno da identidade evangélica. Tese (Doutorado em Antropologia Cultural). UFRJ, Rio de Janeiro, 2017.

BANDEIRA, Olívia; MARQUES, Rafaela. Juridificação reativa e economia da performance. $L A R$, Unicamp. Disponível em: https://www.larunicamp.com.br/novidades/juridificacaoreativa-e-economia-da-performance/ . Acesso em 16 de abril de 2021.

BRown, Wendy. Nas ruínas do neoliberalismo: a ascensão da política antidemocrática no Ocidente. São Paulo: Editora Filosófica Politeia, 2019.

BuRITY, Joanildo A cena da religião pública. Contingência, dispersão e dinâmica relacional. Novos estudos CEBRAP, n.102, 2015, pp. 89-105.

Butler, Judith et al. The power or religion in the public sphere. New York: Columbia University Press, 2011.

Caldeira, Rodrigo Coppe; Toniol, Rodrigo. Catolicismo Eclipsado. Folha de S. Paulo, 31 de julho de 2020. Disponível em: https://saidapeladireita.blogfolha.uol.com. br/2020/o7/31/artigo-mostra-importancia-do-catolicismo-para-ascensao-doconservadorismo-no-brasil/. Acesso em 15 abril/2020.

CAmUrÇA, Marcelo. Religião, política e espaço público no Brasil: perspectiva histórico/ sociológica e a conjuntura das eleições presidenciais de 2018. Estudos de Sociologia, Recife, vol.2, n.25, p.125-159, 2019.

Um poder evangélico no Estado Brasileiro? mobilização eleitoral, atuação parlamentar e presença no governo Bolsonaro. Numpem v.12, n.25, p.82-104, 2020. CARRANZA, Brenda. Apresentação: Erosão das democracias Latino-americanas: a ascensão política dos cristãos. Ciencias Sociales y Religión/Ciências Sociais e Religião, Campinas, v.22, p. 1-17, 2020.

CARRANZA, Brenda; PEREIRA, Gisele Cristina. "Santos e hereges na arena democrática". 2020. Disponível em: Laboratório de Antropologia da Religião -LAR. Disponível: https://www.larunicamp.com.br/novidades/santos-e-hereges/ Acesso em 14 de abril de 2021.

CASANova, José. Public religions in the modern world. Chicago: The University of Chicago Press, 1994.

GiumbelLI, Emerson. A insubmissa diversidade católica. LAR, Unicamp. 17 de novembro de 2021. Disponível em: https://www.larunicamp.com.br/novidades/a-insubmissa- 
diversidade-catolica/?fbclid=IwAR3_A-OhyyehWbsjsoyh3y7Cr7yeUquibNZ_C_3 8bGog7txD3grq-Ju3bOE. Acesso em 16 de abril de 2021.

GuAdAlupe, José Luis Pérez. Evangélicos y poder en América Latina ( $2^{\mathrm{a}}$ ed). Lima: Konrad Adenauer Stiftung (KAS) e Instituto de Estudios Social Cristianos (IESC), 2019.

Intervozes. Monopólios digitais: concentração e diversidade na internet. São Paulo: Intervozes, 2017.

. Desinformação: crise política e saídas democráticas para as fake news. São Paulo: Veneta, 2019.

JunQUEIRA, Rogério Diniz. A invenção da “ideologia de gênero": a emergência de um cenário político-discursivo e a elaboração de uma retórica reacionária antigênero. Psicologia Política, v.18, n.43, p. 449-502, 2018.

LACERDA, Marina Basso. O novo conservadorismo brasileiro. Porto Alegre: Zouk, 2019. Magnani, José Guilherme Cantor. De perto e de dentro: notas para uma etnografia urbana. Rev. Brasileira de Ciências Sociais, v.17, n. 49, 2002.

MaInwaring, Scott. Igreja Católica e política no Brasil (1916/1985). São Paulo, Brasiliense, 2004.

Montero, Paula. Religião cívica, religião civil, religião pública: continuidades e descontinuidades. Debates do NER, Porto Alegre, ano 19, n.33, p.15-39, 2018.

SEmán, Pablo. Quienes son? Por qué crecen? En qué creen? Pentecostalismo y política en América Latina. Nueva Sociedad, n. 280, p.26-46, 2019.

SiLveIra, Emerson José Sena. Tradicionalismo católico e espaço público: a "guerra cultural” dos clérigos ultraconservadores. REB, Petrópolis, v.75, n.300, p. 935-957, 2015.

VAGGIONE, Juan Marco. "A restauração legal: o neoconservadorismo e o direito na América Latina”. In: VAGGIONE, Juan Marco; MACHADO, Maria das Dores Campos; Biroli, Flávia. Gênero, neoconservadorismo e democracia. São Paulo: Boitempo, 2020, p. 41-82. VAGGione, Juan Marco; Machado, Maria das Dores Campos; Biroli, Flávia. "Introdução: Matrizes do neoconservadorismo religioso na América Latina”. In: VAGGione, Juan Marco; Machado, Maria das Dores Campos; Biroli, Flávia. Gênero, neoconservadorismo e democracia. São Paulo: Boitempo, 2020, p. 13-40.

Recebido: 14/12/2020 | Aprovado: 03/05/2021 